\title{
Street Children Survival Strategy Against Violence: Case Study on the Surabaya Ketintang Railway
}

\author{
Rr Nanik Setyowati ${ }^{1, *}$ R.N. Bayu Aji ${ }^{1,}$ Sarmini ${ }^{1,}$ Ali Imron ${ }^{1,}$ Nasihatul Mahmudah ${ }^{1}$ \\ ${ }^{I}$ Faculty of Social Science and Law Universitas Negeri Surabaya, Surabaya, Indonesia \\ *Corresponding author. Email: naniksetyowati@unesa.ac.id
}

\begin{abstract}
Development in the economic sector, as well as science and technology in Surabaya, resulted in very rapid progress. However, development also has an adverse impact on the community, including the emergence of social inequality, both at the national and regional levels. This social gap often raises social problems, including street children and violence. This study aims to determine the forms of violence experienced by street children who do not occupy a shelter in the city of Surabaya and the survival strategy of street children who do not occupy a shelter against violence in the city of Surabaya. This study uses a qualitative approach and takes the location of the gathering of street girls along the railroad tracks in the Ketintang area, Surabaya. According to E. Lawson, there are four forms of violence (abuse) against children and it occurs in the Ketintang railroad area, namely emotional abuse (emotional abuse), verbal abuse (verbal abuse), physical abuse (physical abuse), and violence (sexual abuse).
\end{abstract}

\section{Keywords: Survival strategy, Children Street, Violence}

\section{INTRODUCTION}

Development in the economic sector, as well as science and technology in Indonesia, has made very rapid progress. However, development also raises other problems, namely social inequality and the emergence of street children. Street children are often considered a problem, and there are no regulations that can overcome this phenomenon [1]. Not only in Indonesia, in India and Bangladesh too. Most of the studies on adolescent street boys were conducted either in observation homes or via surveys, but we have adopted a unique approach in which a cross-sectional study was conducted in a 3day 'Diwali Festival Mela', an annual celebration when these adolescent street boys come from almost all areas of Mumbai City in large numbers [2]. Many street children in Bangladesh resort to the streets to void violence at home only to encounter more severe predicaments on the street [3].

So far, society is still constructing street children as a social problem that is difficult to find a solution for. Street children are labeled as community trash, which often causes public unrest. Public unrest begins to emerge when street children deviate, such as stealing, robbing, brawling, and drinking liquor. This condition further strengthens the connotative image of street children in the eyes of the public. Street children in the perspective of developmental psychology are in the adolescent phase, which is characterized by behavior that often wants to separate themselves from their parents to confirm their identity. Of course, the formation of identity, namely the development towards a steady individuality, is an important aspect in the development of being oneself. On the other hand, sociologically, street children will need more peers (peer group) to socialize in a secondary environment.

The attitude of acceptance of street children and knowing their potential is the basis for improving the social welfare of street children because a child can still develop optimally [1]. Many street children do not have good parenting from their families. Parenting is very important for children's development, because the success of forming a child's character is influenced by one of the parents. Therefore, the parenting style according to Baumrind as quoted by Muallifah is "Parental control, namely how parents control, guide, and accompany their children to carry out their developmental tasks towards the maturation process." [4].

Street children included in the category of abandoned children are children whose needs are not met properly, whether physically, mentally, spiritually, or socially. Street children are very vulnerable to crime and exploitation, both economically and sexually. Meanwhile, the United Nations International Children's 
Emergency Fund (UNICEF), defines street children with an age limit of under 16 years who have separated themselves from their families, schools, and their immediate community, and are immersed in a nomadic life on the roads.

Based on the Integrated Social Welfare Data, it was recorded that until 2020 there were 183,104 children with details of 6,572 children in need of special needs, 8,320 street children, 8,507 children under five, 92,861 children requiring social functions, and 64,053 neglected children. Based on their existence, of the 183,104 children, they consist of 106,406 Children in Child Welfare Institutions and 76,698 Children in Families [5]. Street children are part of an antistructured society that is spontaneous and is considered contrary to the established structure. Street children form in groups because they have the same tendencies and patterns among their fellow members, but not in a hierarchical or broad society structure. The logical consequence experienced by street children, as a marginalized group, is that they experience various dimensions of exclusion such as discrimination and exploitation in the social, economic, and political life of the city.

The intensity of the presence of children on the streets is not only motivated by factors of family economic pressure (poverty), but is also influenced by other variables, such as the massive violence that occurs in the family environment, disharmony in the roles and functions of family institutions, and the influence of the social environment [6]. Meanwhile, the findings of the Duta Awam Semarang Foundation, stated that there are at least three factors that cause children to take to the streets, namely economic factors, family problems, and the influence of friends [7].

Apart from these factors, street children must get their full rights, including civil rights and independence, the right to a family environment and choices of care, the right to basic health and welfare, the right to education and culture, and the right to special protection. Handling and empowering street children, get a response from the government through government institutions and also non-government institutions, such as NGOs through shelter houses. However, Sakina's study [8], shows that the empowerment of street children through shelters has not made it an assessment and referral center as well as a facilitator. The coaches have not been quick to respond in solving the problems felt by the foster children. In addition, the relationship of foster children with their families, as well as other institutions is also not optimal. The government only focuses on increasing the number of shelter houses, while improving the quality of shelter houses has not become a top priority.
Therefore, a paradigm shift is needed in placing street children as subjects and providing creative space, and developing their talents and interests, without depriving them of their social rights, the right to education, and avoiding violence. What are the forms of violence that occur in the environment of street children and how their strategies can survive and want to get out of the circle of violence and have become like a spiral that continues to occur both structurally and culturally as a legitimacy for the occurrence of violence.

\section{RESEARCH METHODS}

This study uses a qualitative approach with a qualitative descriptive design, with the consideration of revealing problems naturally without intervention from researchers. Researchers use qualitative research methods, to explore in-depth an event or events that exist. Because qualitative research itself is defined as scientific research that aims to understand an event or event in a natural social context by prioritizing a process of deep communication interaction between the researcher and the event or event being studied.

In 2021 , this study aims to describe the forms of violence experienced and strategies for surviving street children who do not occupy shelters against violence in the city of Surabaya.

The source of data that the author uses in this study is the type of primary data and secondary data, where primary data is data directly collected by researchers from the first source. The primary data in this study are field findings derived from interviews with informants in the field. Trying to collect data from various informants with various variants. While secondary data is data obtained indirectly in the form of documents, which can also be said as additional data that is used as a reference and elaboration of primary data such as books, research journals, research documents, information from the mass media, and so on, regarding violence. against street children who do not occupy a halfway house in the city of Surabaya.

The theory that will be used uses Johan Galtung's theory which divides violence into three categories [9], namely direct violence (between perpetrators and victims), structural violence (sourced from social structures (between people, communities, groups of people), and cultural violence (symbolic in religion, ideology, language, art, knowledge, law, media, education) the point is to legitimize direct violence and structural violence[10]. This is then followed by Terry E. Lawson in Huraerah who states that there are four forms of violence (abuse) against children, namely emotional abuse, verbal abuse, physical abuse, and sexual abuse [11]. 


\section{RESULT AND DISCUSSION}

Street children are often found in busy places such as railway stations, bus stations, in front of film or nightclubs, with no adult supervision, sleeping in halfdestroyed houses, abandoned basements, under bridges, and in the open air. street children survive on the streets through conventional and unconventional ways such as rubbish picking, shoe shining, flower selling, petty crimes, drug abuse, begging, panhandling, prostitution, petty theft; and drug trafficking. They also develop passive and aggressive attitudes, replacing their families with street gangs and experiencing social, sexual, physical, and emotional abuse. Streets throughout the world are home to millions of children who endure hardships and injustices while struggling to survive [12].

Table 1. Informant Profile

\begin{tabular}{|c|c|c|c|}
\hline Nu. & Name & Education & Information \\
\hline 1. & $\begin{array}{l}\text { RS, } 10 \text { years } \\
\text { (female) }\end{array}$ & $\begin{array}{l}\text { 5th } \\
\text { elementary } \\
\text { grades }\end{array}$ & $\begin{array}{l}\text { Lives along the } \\
\text { railroad tracks, } \\
\text { Ketintang Baru, } \\
\text { Surabaya. The } \\
\text { son of a } \\
\text { scavenger who } \\
\text { has separated } \\
\text { from his father. }\end{array}$ \\
\hline 2 & $\begin{array}{l}\text { YF, } 12 \text { years } \\
\text { (female) }\end{array}$ & $\begin{array}{l}\text { Class VIII } \\
\text { junior high } \\
\text { school }\end{array}$ & $\begin{array}{l}\text { Lives along the } \\
\text { railroad tracks, } \\
\text { Ketintang Baru, } \\
\text { Surabaya. YF } \\
\text { has two younger } \\
\text { siblings. Since } \\
\text { childhood YF } \\
\text { lived with his } \\
\text { parents. }\end{array}$ \\
\hline 3 & $\begin{array}{l}\text { BG, } 9 \text { years } \\
\text { (male) }\end{array}$ & $\begin{array}{l}\text { 4th-grade } \\
\text { elementary } \\
\text { school }\end{array}$ & $\begin{array}{l}\text { Lives along the } \\
\text { railroad tracks, } \\
\text { Ketintang Baru, } \\
\text { Surabaya. BG } \\
\text { lives with his } \\
\text { mother who } \\
\text { works as a } \\
\text { factory worker. } \\
\text { His father had a } \\
\text { bad character and } \\
\text { was often violent } \\
\text { towards him. }\end{array}$ \\
\hline
\end{tabular}

\subsection{Background of Violence Experienced by Street Children}

The results in the field show that street children who live on the edge of the railroad are vulnerable to violence that is often perpetrated by the child's immediate environment, one of which is mental (psychic) violence and sexual violence. As felt by RS (pseudonym). The case experienced by the hospital (10 years) experienced bullying by the environment and his friends. RS is shunned by his friends because of his mother's job as a scavenger.

RS's mother is a widow who has long been divorced from RS's father. RS's mother is often rumored as a woman who is not good by the surrounding environment. RS's mother is also often rumored to have had sex with men, remarried, and was labeled bad by neighbors. RS also often gets ridiculed by his friends because he often receives calls from his girlfriend (often communicates with his girlfriend via telephone). According to the hospital's narrative, the bullying carried out by the surrounding environment made the hospital not confident enough to join in playing with his friends. RS is also often not invited to play by his friends because of his family's condition. RS chose to stay home or help his mother instead of joining his friends.

Table 2. Violence Experienced by Street Children Who Don't Occupy a Shelter House in Surabaya

\begin{tabular}{|l|l|l|l|}
\hline Nu. & Name & $\begin{array}{l}\text { Form of } \\
\text { Violence }\end{array}$ & Information \\
\hline 1. & RS & $\begin{array}{l}\text { Verbal } \\
\text { violence }\end{array}$ & $\begin{array}{l}\text { Ridiculed/insinuated } \\
\text { and shunned by his } \\
\text { friends. }\end{array}$ \\
\hline 2. & YF & $\begin{array}{l}\text { Sexual } \\
\text { violence }\end{array}$ & $\begin{array}{l}\text { Showed the genitals } \\
\text { of a man named Pak } \\
\text { Burung (Mister P). }\end{array}$ \\
\hline 3. & BG & $\begin{array}{l}\text { Physical } \\
\text { violence }\end{array}$ & $\begin{array}{l}\text { Poorly educated by } \\
\text { his parents so he } \\
\text { behaves badly and } \\
\text { often teases his } \\
\text { friends. }\end{array}$ \\
\hline
\end{tabular}

Cases of sexual violence are also often experienced by children who live in settlements by rail. One of the cases that occurred was in a residential area on the edge of the rail, where there was the house of a middle-aged man whom the children referred to as "Pak Burung". The father often commits indecent acts to the child. $\mathrm{He}$ showed his genitals to the children who passed in front of him. According to residents around the location, "Mr. Burung" is a bit mentally disturbed, but his actions are very unjustified and disturbing. According to YF (12 years old), he and his friends were so scared that they 
didn't dare to pass in front of the father's residence. YF said that he and his friends tended to be silent when the father carried out his actions and did not dare to tell anyone about the incident unless there was an adult who asked and told an adult they trusted about the incident.

Likewise, children who live in rail-side settlements also do not receive love in the form of proper parenting from their parents, so they tend to seek attention with actions such as disturbing others to get attention. Like the action taken by BG (9 years old) when the researcher was visiting a railroad settlement, where BG disturbed people he had just met by throwing toy firecrackers. The results of the narrative from one of the neighbors of BG stated that BG's parents were divorced and BG lived with his father. Even though BG's actions are meant to be playful, they cannot be justified because they can harm other people.

\subsection{Survival Strategy from Street Child}

The strategy carried out by RS (pseudonym) in dealing with various forms of bullying or verbal violence carried out by friends and their environment, is trying to get back together with their playmates even though based on RS's narrative he still gets a negative response and indifferent attitude from his friends. In the end, what RS did was to be indifferent to his friends and environment, to let whatever was said and gossip about him and his mother. According to RS, he is also often shunned and his friends don't want to invite him to play, as he said in the following interview.

"Aku lo mbak ogak tau diajak karo mblokane arek kui, mesti ngajak bolo-bolone thok”.

(I was never invited by other friends, they only invited their friends). (Interview, March 25, 2021)

Based on the results of these interviews, we can get an idea of how the hospital's friends respond in responding to what they do in their daily activities their social environment, as a result, the hospital also doesn't pay attention and tends to be silent.

Meanwhile, YF and his friends are to complain or notify the father's dishonorable actions to adults or people they trust. Another strategy needed to overcome so that children can be protected from harmful actions is to provide special assistance carried out by certain parties, one of which is from Non-Governmental Organizations (NGOs). The Surabaya ALIT Foundation is one of the foundations engaged in child protection and has the wrong target group, namely children who live along the edge of the Ketintang Baru railway. The ALIT Foundation seeks to protect the form of training and education activities that are provided directly to the assisted children. The ALIT Foundation also provides several materials in the form of child protection modules for assisted children regarding ways that can be done to protect themselves from situations that endanger children.

The strategy that can be done is to assist children, especially children who do not get special attention from parents. This condition causes children to have tantrums more easily and take actions aimed at getting the attention of those around them. The Surabaya ALIT Foundation also provides a form of assistance to parents of children who live on the edge of the rail by forming a parent forum, where the forum serves as a medium of communication with children's parents so that they understand good parenting methods and prioritize the fulfillment of children's rights. without resorting to violence against children.

Table 3. Strategi to survive the Violence Experienced by Street Children Who Don't Occupy a Shelter House in the City of Surabaya

\begin{tabular}{|c|c|c|c|}
\hline Nu. & Name & Defensive Strategy & Expectation/hope \\
\hline 1. & RS & $\begin{array}{l}\text { Trying to continue } \\
\text { hanging out with } \\
\text { her friends, even } \\
\text { though he still gets } \\
\text { a negative response. } \\
\text { She is indifferent } \\
\text { and lets his friends } \\
\text { talk about him and } \\
\text { his mother }\end{array}$ & $\begin{array}{l}\text { No one bullies and } \\
\text { wants to be friends } \\
\text { with him. He hopes } \\
\text { that no more of his } \\
\text { friends will be bullied. }\end{array}$ \\
\hline 2. & $\mathrm{YF}$ & $\begin{array}{l}\text { Reporting acts of } \\
\text { violence they } \\
\text { experience to adults } \\
\text { and people they } \\
\text { trust. Asking for } \\
\text { assistance from the } \\
\text { right institution, for } \\
\text { example, a Non- } \\
\text { Governmental } \\
\text { Organization } \\
\text { (NGO), ALIT } \\
\text { Foundation. }\end{array}$ & $\begin{array}{l}\text { No more acts of } \\
\text { violence committed by } \\
\text { adults, for example, } \\
\text { abuse of sex. Hope that } \\
\text { others can respond to } \\
\text { acts of violence that do } \\
\text { not happen again } \\
\text { because it is done } \\
\text { repeatedly. }\end{array}$ \\
\hline 3. & $\mathrm{BG}$ & $\begin{array}{l}\text { Assist children, } \\
\text { especially children } \\
\text { who do not get } \\
\text { special attention } \\
\text { from parents. This } \\
\text { causes the child to } \\
\text { take more action to } \\
\text { seek the attention of } \\
\text { the people around } \\
\text { him. }\end{array}$ & $\begin{array}{l}\text { Get the love of his } \\
\text { parents and can } \\
\text { continue his education } \\
\text { to achieve his goals. } \\
\text { Besides, he hopes that } \\
\text { his divorced parents } \\
\text { will get along well. }\end{array}$ \\
\hline
\end{tabular}




\section{CONCLUSION}

This study provides a glimpse of how psychological, sexual and physical abuse is a problem that occurs among street children and how they can survive the situation. This happens because of social inequality and also an unorganized family environment that is not good and is supported by an increasingly permissive community environment. Street children who experience violence also tend to be silent if no one else is paying attention. Several NGOs such as ALIT are very helpful in assisting street children in the railroad environment in the Ketintang area who are experiencing violence so that they are not only able to survive but also dare to choose an attitude and act and take resistance in the sense of being brave to report it so that the chain violence can be cut off. The fulfillment of the basic rights of street children must also be carried out so that street children can be increasingly free from violence.

\section{ACKNOWLEDGMENTS}

I would like to thank the Faculty of Social Sciences and Law, Universitas Negeri Surabaya who support this research.

\section{REFERENCES}

[1] P. Armita, "Meningkatkan Kesejahteraan Sosial Anak Jalanan dengan Teori Self Esteem.," J. PKS, vol. 15, no. 4, pp. 377 - 386, 2016.

[2] A. Gaidhane, Q. S. Zahiruddin, L. Waghmare, S. Shanbhag, S. Zodpey, and S. R. Joharapurkar, "Substance abuse among street children in Mumbai," Vulnerable Child. Youth Stud., vol. 3, no. 1, pp. 42-51, 2008, DOI: 10.1080/17450120701843166

[3] M. H. Reza, "Street children's use of social support against everyday abuse in Bangladesh," Child Youth Serv., vol. 38, no. 4, pp. 285-301, 2017, DOI: 10.1080/0145935X.2017.1326307.

[4] Siswanto, "Pembinaan Anak Jalanan Melalui Pola Asuh di Rumah Singgah dan Belajar (RSB) Diponegoro Sleman Yogyakarta," HISBAH J. Bimbing. Konseling dan Dakwah Islam, vol. 16, no. 1, pp. 59-73, 2019.

[5] M. of S. Affairs, "No Title," https://kemensos.go.id/accessed, 2021.

[6] A. Subhansyah, Anak Jalanan di Indonesia: Deskripsi Persoalan dan Penanganan. Yogyakarta: LPSH Humana, 1996.

[7] D. Awam, "Laporan Tahunan Yayasan Duta Awam Semarang," Semarang, 2007.

[8] L. Sakina, "Penilaian Anak Jalanan terhadap
Pelayanan Rumah Singgah dan Hubungannya Dengan Perilaku Mereka: Kasus Rumah Singgah Bina Anak Pertiwi, Kelurahan Jati Padang, Kecamatan Pasar Minggu, Jakarta Selatan,' Institut Pertanian Bogor, 2011.

[9] Johan Galtung, "Violence, Peace, and Peace Research," J. Peace Res., vol. 6, no. 3, pp. 167191, 1969.

[10] J. Galtung, Peace by Peaceful Means, Peace and Conflict, Development and Civilization. London: PRIO and SAGE Publications, 1996.

[11] Abu Huraerah, Child Abuse (Kekerasan Terhadap Anak). Bandung: Nuansa, 2017.

[12] Y. M. Bah, "Drug Abuse Among Street Children," Biomed. J. Sci. Tech. Res., vol. 10, no. 4, pp. 1-19, 2018, doi: 10.26717/bjstr.2018.10.001982. 